\title{
The world of Chinese fictional narratives: content, characters and social impact
}

\author{
Olga Leontovich ${ }^{1}$ (1)
}

Received: 6 October 2015/Revised: 21 October 2015/Accepted: 22 October 2015 /

Published online: 6 November 2015

(C) Academy for International Communication of Chinese Culture and Springer-Verlag Berlin Heidelberg 2015

\begin{abstract}
Chinese narratives in their various forms serve as an invaluable source of information about China, its rich history and culture, its citizens' identity, values, and the way they conceptualize reality. This paper is part of a broader research of Chinese narratives that is being carried out by a group of Russian scholars. The study is done on the intersection of different disciplines, mainly linguistics, semiotics, and communication studies. The approach taken in the study can be described as a mixed method research design, in which narrative analysis is employed as the leading method. The paper discusses the universal and culturally specific dimensions of fictional narratives, with an emphasis on myth; analyses Chinese fictional narratives as an instrument of conceptualizing reality through the prism of national identity, mentality, and worldview; investigates the influence of mythological constructs on modern Chinese society. The findings indicate that the results of the research can be further extended to other types of Chinese narratives and can lead to their practical application in text interpretation, education, literature studies, and intercultural communication contexts.
\end{abstract}

Keywords Chinese $\cdot$ Narrative $\cdot$ Fictional $\cdot$ Myth $\cdot$ Worldview

\section{Introduction}

Chinese narratives in their various forms serve as an invaluable source of information about China, its rich history and culture, its citizens' identity, values, and the way they conceptualize reality. This paper is part of a broader research of

Olga Leontovich

olgaleo@list.ru

1 Volgograd State Socio-Pedagogical University, 27 Lenin Prospect, Volgograd 400066, Russia 
Chinese narratives that is being carried out by a group of Russian scholars from Volgograd State Socio-Pedagogical University and supported by a grant (No 15-0400500) from the Russian Foundation for Humanities. The study is done on the intersection of different disciplines, mainly linguistics, semiotics and communication studies. Its aims are to list different types of Chinese narratives, describe their origins, logic and structure, historical dynamics, cultural background, linguistic expressive means and stylistic devices. The main emphasis is made on myths, fairytales, comedic and cinematographic narratives, as well as traditional and modern narrative songs.

The goals of the present paper are: (1) to discuss the theoretical framework of narrative analysis, giving special attention to social constructionism; (2) to identify the universal and culturally specific dimensions of fictional narratives, with an emphasis on myth; (3) to analyse Chinese fictional narratives as an instrument of conceptualizing reality through the prism of national identity, mentality, and worldview; (4) to investigate the influence of mythological constructs on modern Chinese society.

\section{Research methods}

The approach taken in the study can be described as a mixed method research design, in which narrative analysis is employed as the leading method. The latter has its roots in the works of such scholars as de Saussure (1916), Bally (1932), Levi-Strauss (1955, 1958), and others. A great contribution to the research of narratives was made by Russian Formalists, especially Propp (1928). The term "narratology" was coined in 1969 by Todorov. The method was further developed by a number of other scholars, e.g., Genette (1972, 1983) and Jahn (1999) and applied not only to verbal texts but also other narrative forms, such as films, comics, music, ballet, etc. We adhere to this broad understanding of the field, which allows for a comprehensive analysis of narratives of different forms and genres.

The criteria used in this study to characterize a text as a narrative are: the presence in it of a narrator; a reader or listener; characters; sequence of events; causal relations between them; finality of the plot; and the narrator's attitude towards what is being told. We mostly employ structural narrative analysis, paying special attention to the mechanism of narration, recurrent elements, themes, and text models, the combination of which affects the character of the narrative as a whole. The data is analyzed from three perspectives: temporal, spacial, and social. The method implies a detailed study of the relationship between different technical and symbolic elements, codes, conventions, etc. We take into account not only the information that is expressed explicitly, but also inferences, cultural presuppositions, allusions, reminiscences, and intertextual connections. This allows us to give an indepth interpretation of the narrative and provides a holistic multidimensional approach towards its study.

Other methods include: semiotic, discourse, and stylistic analyses.

We employ semiotic analysis to investigate how different kinds of signs (verbal, non-verbal, behavioral, etc.) construct Chinese fictional narratives. We do so by 
performing the following procedures: (1) single out the key signs; (2) carry out their primary analysis to identify the signifier and the signified; (3) find out how their choice influences the generation of meanings; (4) study the connection of signs with each other; (5) observe their sequence, spacial and structural relationship; (6) analyse the text from the point of view of intertextuality-see how the signs relate to other ones in different narratives; (7) identify signs which act as cultural markers; (8) see how the signs are contexualized in different social settings; (9) find out how they were interpreted historically and are perceived nowadays. In order to attain a semiotic view of the Chinese narrative world, it is critically important to observe the signs in their interaction, mutual influence and dynamics in time and space.

The use of elements of discourse analysis gives us an opportunity to study the macro- and micro- context of the narrative; discuss communicative actions and interactions; observe both verbal and non-verbal aspects of discourse; investigate the unfolding actions in a social, cultural, and cognitive contexts, etc. (see Van Dijk 1981).

Stylistic analysis is used to identify lexical and syntactical expressive means and stylistic devices, such as epithets, metaphors, metonymies, and other figures of speech employed to express emotions or evaluate actions and events. We give special attention to culturally specific ways of imagery formation.

The suggested algorithm of analysis allows us to see the unfolding of meanings in a narrative, interpret them, identify culturally marked elements, and see the regularities of their realization in a context. This approach is also effective for the study of the historical development of narratives from ancient times to the present day and their influence on modern Chinese society.

\section{Fictionality and social constructionism}

Fictional narrative is a product of fantasy and human creativity, It tells us about made-up worlds and reflects the modes of conceptualization and categorization of reality typical of a particular culture. Nowadays fiction is an object of study in philosophical ontology, theory of cognition, discourse analysis, linguistics, and other disciplines. Scholars seek to find out: (1) how reality opens up opportunities for fiction; (2) how fantasy as a human ability realizes those opportunities and in its turn influences reality; (3) what is the correlation between fictional and factual knowledge, credibility and lies, truthfulness and fabrication in fictional discourse.

Fantasy is an inherent part of the human mind. Human cognition is stimulated by the need to explain the inexplicable and find one's own place in the universe. According to Shilkov, people's ability to create imaginary worlds "suggests the existence of 'a priori' mechanisms of their production as ontological concepts" (Shilkov 2002). Such mechanisms are brought into motion in the face of the unknown; they include the ability to create models and establish logical connections.

This approach correlates with social constructionism, a research area that was formed in recent decades and advanced in sociology, psychology, communication 
theory, etc. The ideas of social constructionism are formulated in the works of Burr (1995), Cronen (1996), Gergen (1991), Pearce (1994), Powers (1994), Spector and Kitsuse (1977), and others. The ideas of social constructionism are useful for the understanding of how the human mind constructs fictional worlds, therefore we will take a brief look at its basic notions.

Some of the provisions of social constructionism which reflect its essence are summarized below: (1) social reality is constructed by people in the process of communication as a continuous negotiation process; (2) the knowledge about the world does not belong to one individual, it is a product of human interaction; (3) communication is a primary social process, a mode of human existence; it is not aimed at the maintenance of other social practices, but is socially significant in itself; (4) there are no truths universal for all societies, social discourse is a form of knowledge functioning within a particular social group; (5) the world is constructed not only cognitively, but also linguistically; (6) the forms of expression by means of which people understand the world are culturally conditioned; (7) social knowledge can influence social practices.

The adherents of social constructionism assert that the view of society is not projected from reality - it is formed in the process of communication as a product of human interaction. As Stoljarova puts it, objects of reality are interpreted as "dialogue objects." She further points out that "what "nature' communicates to us depends not only on its 'real' organization, but also on the position of the enquirer." This position, in its own turn, is not straightforward but is determined by the relationship system (Stoljarova 2003).

Personal identity is also a product of interaction, it is formed on the basis of people's self-identification and their perception by others. Both are formed as a result of their life experiences, education, observation, imitation, adopting values, beliefs, and convictions viewed as a norm in their community. This is probably what allows Carbaugh to write about the socially discursive origin of self (Carbaugh 1996 , p. 6). In order to exist in society, people use trial and error approach to discover modes of communicative behavior which would allow them to survive and adapt to their social environment. Since norms are created by society, they are seen as part of an objective reality but, unlike the laws of nature, some of them can be accepted and others rejected.

The world viewed as a "product of human subjectivity" (Kujarova 2007) is in fact a product of interpretation. Individuals regarded from the perspective of social constructionism cannot be sure that they see the world 'correctly,' because what is 'correct'? Each person has a unique world view and one's own understanding of what is right and wrong. The perception and comprehension of the world is achieved through concepts and categories, which do not exist objectively but are social constructs.

The claim that there are no truths universal for all cultures is a reflection of the relativity approach typical of social constructionists. They believe that there are no proofs of the 'validity' or 'falsehood' of constructions through which people perceive the world at large. Gergen asserts that science, logic, mythology, religion, mysticism, public opinion, and literature all have equal claim to truth (qtd. from: Smith 2003). 
In some ways social constructionism merges with postmodernism the representatives of which raise subjectivity of world perception to an absolute, thus admitting that the world is non-cognizable and that individuals have the privilege of constructing their own reality.

While adopting some of the ideas of social constructionism, we prefer the moderate relativism approach, which takes into account "the inclusion of a human being as a constituent of the holistic world order," "co-creativity of man and nature" (Stoljarova 2003). This approach allows us to make use of the strengths of social constructionism without taking subjectivism to an extreme beyond which it becomes an absurdity.

It can be argued that an individual's social world is constructed on the basis of the following factors: (1) actual reality; (2) its collective perception by representatives of society through the prism of the existing system of values, beliefs, ideologies, economic relations, etc.; (3) the individual's personal qualities, perceptions, and convictions. Those three factors are closely connected with a particular culture: the objective reality, which constitutes the social context of human interaction, possesses its nationally specific features reflected in the landscape, architecture, climate, people's appearance, language, non-verbal communication, etc.

One of the most important provisions of social constructionism is the idea that "the discursive 'structure' presupposes the influence of sociocultural knowledge on social practices" (Makarov 2003, p. 64). It means that the way the social setting is reflected in people's minds affects their actions and can bring about social changes. Therefore, the study of social constructs is of practical importance on both monocultural and intercultural levels and helps to understand the influence of myth on people's mentality, values and patterns of behaviour.

The world is constructed not only cognitively, but also linguistically and discursively. We find out about other people's perception of the material and social environment by communicating with them. Therefore, the study of narratives allows us to avoid speculative approaches and study different aspects of the constructed world through their verbal representations. The borders and attributes of fiction are dynamic and change with the extension of the limits of human knowledge.

People narrating about their relationship with the world use different linguistic means that reveal the inner motives of their behaviour. The choice of words, construction of sentences, the use of figurative language and communication strategies all make a difference. As Lyotard puts it, everything people say about their actions, convictions, and desires falls within the framework of their social and individual practices and constitutes their individual being. Narratives are universal as a mechanism of organizing human experience; they possess social instrumentality and pragmatic potential (Lyotard 1998).

The key idea of narrative analysis - the leading method of our research-is the perception of human life as a continuous process reflecting social phenomena. In this process attention is switched from "real life" to the way it is interpreted by the storyteller, and this is the central feature of our approach to fictional narratives. 


\section{The nature of myth}

Myth occupies a significant place among different fictional genres. Barthes views it as a signification mode, communication system, and message. Since myth is speech (parole), Barthes says, anything worthy of a narrative can become it, as "the universe is infinitely suggestive. Any object of the world can pass from a closed, mute existence to an oral, open state to be appropriated by society..." (Barthes 1957, p. 181). It is evident that Barthes' interpretation extends the limits of mythological narrative beyond the borders of what is traditionally viewed as mythology.

Barthes also emphasises the dynamic of mythological narrative and its connection with the historical time: both in ancient times and today mythology can only have its foundations in history "because myth is speech (parole) chosen by history, it cannot arise from the "nature' of things" (Ibid).

An important characteristic of myth is its relation to the real world because any kind of fantasy is based on reality which serves as a starting point for the unfolding of fictional discourse. Every epoch has its own limits of departing from reality, outside which myth will no longer be regarded as good narrative. As Aristotle put it, "in a poetic work the probable impossible is always preferable to the improbable possible."

For the understanding of myth it is also important to discuss the correlation of fiction and truth, fantasy and lies. When Walsh regards fictional discourse from the perspective of truthfulness, he indicates that the relevance of the message in it prevails over truthfulness because from the very start fictional discourse does not pretend to be truthful-it is based on indirect expression, inferences and needs to be interpreted (Walsh 2007, p. 30). This corresponds to Barthes' opinion that myth does not hide anything-its function is to deform, but not conceal, and there is no need to resort to the unconscious to interpret myths (Barthes 1957, p. 181).

Therefore, it is possible to assume that, unlike lies, myth does not aim to mislead or deceive. Fictional discourse is a game of sorts, which is understood both by the narrator and the audience. The tacit agreement that fiction is not a lie is accepted by the participants of discourse and is secured by cultural and communicative conventions. It can be argued that sometimes the narrators are convinced that they are telling the truth, i.e. when it relates to religion, prejudice, ideological convictions, etc. But it is important that in such cases they are not trying to deceive or manipulate the audience either. In connection with this Shilkov remarks that fiction belongs to creative genres, whereas lies don't (Shilkov 2002).

The functions of fictional discourse can be summarized as follows: (1) it interprets the past experiences; (2) it strives to explain the inexplicable; (3) it works as an instrument of conceptualization and categorization of reality; (4) it is a product of imagination and creative activity; (5) it can act as a means of departing from reality; (6) it amuses and entertains; (7) it is an attempt to predict and model the future; (8) it shows the direction for quest, creative ideas and plans; (9) it helps to understand other people and cultures; (10) it influences social practices. 
There is a close connection between imagination, inclination to fantasy and aptitude for scientific discoveries. As Faraday remarks, "Science benefits when its wings are liberated by fantasy."

In many ways myth acts as a "fantasy liberator." It extends the limits of our universe, creates new landscapes, inhabits them with unknown creatures, forms connections between them, and establishes new modes of behaviour, extrapolating the rules of human social communication to the mythological world.

Summing up what has been said above, we can characterize myth as a specific type of fictional narrative in which fantasy is based on reality. A tacit agreement between the participants of discourse that myth is not a lie but rather a game is secured by cultural and communicative conventions. Fantasy liberates the human mind and stimulates cognition.

\section{Chinese mythology}

Mythology exists as a corpus of texts united by intertextual connections. This is a whole world based on its own philosophy, ethics, rules, norms, and conventions.

Chinese myths have reached us as a heterogeneous collection of archaic beliefs retained in the context of philosophical, literary and historical texts the authors of which often gave them their own interpretation. That is why they exist in a variety if versions (Encyclopedia of Mythological World 1999, p. 179).

Chinese mythology is based on a unique religious and ethic system in which the old worldview is supplemented by the organically coexisting ideas of Taoism, Confucianism, and Buddism (Rodin 2004, p. 10). It constitutes a complex model of the world, with a detailed context of interaction and a dense network of connections between characters, reflecting the history of the most ancient civilization on the planet. It therefore gives scholars a unique opportunity to observe the dynamics of the human mind in general and Chinese mentality and values in particular.

We will further investigate the construction of fictional reality in mythological narratives via a number of parameters, such as a macrocontext of interaction, locus, time, characters, their communicative behaviour, ways of categorization of reality, cultural symbolism, and logic of meaning.

\section{Macrocontext of interaction}

The world of ancient myths is much broader than the world of today's rationally thinking humans. According to Chinese mythology, the world was created of water chaos called Hundun (or Hun-tun). Different sources claim that it had the shape of an egg inside which Pangu (Pan Gu, P'an $\mathrm{Ku}$ ), "the fashioner of the Universe" (Werner 2005), emerged. The beginning of the world is associated with Pangu's growth and the separation of the sky from the earth. Pangu had slept in the egg for 18,000 years and then broke it with an axe. As a result, everything light and pure rose up and formed the sky, and everything heavy and dirty sank down and formed the earth. Then Pangu "pushed the heaven and earth apart with a loud crack" (Chinese Tales) and stood like this for another 18,000 years. As he grew, the sky 
and the earth moved further apart until the distance reached the present 90,000 li (Samozvancev 2000, p. 254; Ezhov 2004, p. 43). When this happened, "the breath which escaped his lips became the wind and clouds, his voice turned into thunder, his left eye became the sun and his right eye-the moon, his body with his hands and feet formed the four sides of the world, his blood turned into rivers, his veins into roads, his flesh into soil, his hair and moustache into stars in the sky" (Ke 1965). After Pangu's death his elbows, knees and head formed five sacred mountain tops, his body hair turned into trees and grass and parasites on his body-into people (Encyclopedia of Mythological World 1999, p. 179).

The myth of Pangu may prove that China belonged to those ancient cosmogonic systems where space was likened to a human body, thus showing the unity of the macro- and microcosm (Samozvancev 2000, p. 255; see also Encyclopedia of Mythological World 1999, p. 179; Werner 2005).

\section{Locus}

To understand the microcontext of mythological discourse, it is important to remember that the Chinese position themselves as the 'Central Kingdom,' the centre of the universe, whereas the rest of the world is 'zhongwai' - the 'outskirts.'

The landscape of the earthly world in Chinese mythological narrative is very much like China itself. It consists of rivers and mountains, whereas forests, plains, and deserts are scarce. The old character for "Earth" represented a heap of earth, i. e. was based on the identity of earth and mountain. Taoism is associated with the Five Sacred Mountains. Fantasies rely on what is familiar and accessible, but are built around what is unknown and unattainable (the earthly and celestial worlds, storms, the stars, the moon, etc.).

The description of locus is characterized by the love of accuracy and concreteness so typical of the Chinese. For example the "Classic of Mountains and Seas" (4th-5th A.D.) describes the exact position of the sacred island Yíngzhou: in the Eastern Sea 700 thousand li from Kuiji in the Zhejiang province. The ancient poem "Lieh Tzu" gives the exact dimensions of each of the great mountains (Daiyu, Yuanjiao, Fangzhang, Yíngzhou and Penglai) that once floated in the abyss Guxu-30 thousand li, the plateau at the top-9 thousand li, the mountains are 70 thousand li apart from each other (Mifologicheskij slovar' 1990).

In fairy tales, too, the place of action is often indicated: Shu Kingdom, Song Empire, Chang'an city, Zheng State, the western side of the village. One of the fairy-tales begins like this: “Тюо mountains, Dakeng и Wang Wu, occupied the space of $700 \mathrm{li}$ and were 10 thousand chi high. They were situated to the south of Yíngzhou and to the north of Huang he" (Plotnikova and Jujshina 2008, p. 190).

The analysis shows that the macrocontext of interaction in Chinese mythological narratives embraces the universe, with China as its centre. The landscape described with great accuracy is typical of China and is represented by the ocean, earth, mountains, and rivers. 


\section{Time}

In the context of narrative analysis time acquires special significance because the narrators have a lot of power over it: they decide which event should be described in more detail and which just mentioned in passing; how to distribute the events-in strict chronological order or with deviations from it. The notion of discursive time is used to describe the real length of the event, whereas narrative time denotes the period it takes to relate about it. "Fictional time,"-Y. Shilkov remarks, "as well as space, can be split into an indefinite number of dimensions" (Shilkov 2002).

The peculiarities of Chinese fictional time are: its cyclic perception, orientation towards the past, tendency to give a concrete description of time because of the absence of Chinese verb forms denoting past or future tenses, e. g., "during the time of the Ming dynasty," "during the time of the Song dynasty," "at that time state Wu was at war with state Yue."

In fairy-tales retold in English, those phrases are transformed into "once upon a time," "long, long ago," "there once lived," to make them more appealing to the Western reader. Instead of a concrete indication of time and place, we come across such initial phrases as: "A long time ago in a certain part of China...," "Once upon a time in a small town in the land of China..." The indication that Pangu held up the sky for 18 thousand years is changed into "for a great long time." This wording shows the difference in the Western and Eastern perceptions of time and space.

\section{Characters}

The world of Chinese mythological characters is densely populated and diversified. We do not aim to classify and describe all the characters but are more interested in the features ascribed to the 'population' of the fictional worlds by Chinese 'collective consciousness.'

There are thousands of Chinese mythological characters, such as progenitors of mankind, deities of nature, patrons of crafts, immortal geniuses, mythical heroes, all kinds of spirits, etc. For example, the Taoist Pantheon, alongside with other deities, included door gods, bed gods, toilet gods, temple guards, etc. (Kitajskaja mifologija).

The anthropomorphic characters are represented in myths, legends and fairy-tales as real people or human-like creatures: deities (e. g., Jade Emperor Yù Huang, or $\mathrm{Yu}$ Di), heroes (such as Cao Cao, one of the most powerful figures of the Three Kingdoms period), as well as common people (teacher, father, son, carpenter, cobbler, fortune teller, monk, warrior, eleven lazy men, drunkard, etc.).

The world of fantasy also abides in fictitious characters, more numerous than real ones. They include human-like characters with zoomorphic features: semi people, semi-animals. For example, the progenitor Nuwa-the creator of all things and people-has a human head, human arms and the body of a snake; she and her husband and brother $\mathrm{Fu} \mathrm{Xi}$ are usually featured as a pair of creatures with intertwined tails of snakes or dragons that symbolize intimacy in marriage. Xī Wang $\mathrm{Mu}$, the ruler of the West, possesses a human body, a leopard's tail and a tiger's fangs; Feng Bo, god of the wind, looks like a dog with a human face; giant Chiyou 
has a human body, six arms, a copper head with an iron forehead and a sharp horn, four eyes, hooves and wings; Bazha, a mythological creature that eliminates locusts, is depicted with a bird's legs, a human face and a nose which looks like a beak, it has strange patches of hair behind its ears which look like horns. The just ruler Di $\mathrm{Ku}$ is featured with a bird's head and a monkey's body.

Zooanthropomorphism is interpreted by many scholars as the reflection of totemism (e. g., Samozvancev 2000, p. 251). On the other hand, such diversification can be explained by an attempt to visualize the unknown and find a place for it in the model of the world created in a particular culture. Human-like qualities of the unknown creatures make them apprehensible for the human mind; their fictitious features set them aside from real people (hence hybridization and made-up qualities). This can partially explain why with the time flow strange mythological characters were transformed into humans, some female characters-into beauties, etc. As the knowledge about the world grew and humans adapted themselves to the world at large, there was a tendency towards a more realistic representation of mythological creatures.

It is also worth noting that in art and sculpture the fictional characters always preserve the physiological features of the Chinese people, i.e. are represented through the Chinese ethnocentric worldview and preserve their ethnocultural specifics.

Another type are mythological characters who are human-like but, however, possess non-human qualities. This is also a way to differentiate between the real and fictional worlds. Samozvancev points out that many spirits and deities are asymmetrical or, on the contrary, possess multiple human body parts - these are creatures with one leg, one eye, two heads, etc. (Samozvancev 2000, p. 268). E.g. Doumu, "Big Dipper Mother" who is in charge of life and death, is represented with four faces and eight arms; huoxing, a spirit of fire and the personification of Mars, has two faces (cruel and kind) and six arms.

The inhabitants of mythological lands are people with intertwined legs, drill-like teeth, long ears (hanging down to their shoulders, so that they have to hold them when they walk), holes in their chests for carrying heavy things on a pole, with one arm, one eye and one nostril, with falling heads (which can break away and fly with the help of ears which perform the function of wings); with tongues inside out, etc. There are also lands of people with black teeth, or dark legs, or pig snouts, the land of pygmies, savages, etc. (Ezhov 2004, pp. 56-70).

The description of lands with those strange people is a tribute to the 'otherness' of cultural groups that did not fit into the Chinese habitual worldview, a reaction to the cultural variety of real life combined with an attempt at rationalization. This opinion agrees with historical data-e.g., the authors of the Encyclopedia of Mythological World (1999, p. 188) point out that during the Han period many Chinese travellers set off for far-away lands and on coming back described foreigners in derogatory terms, comparing them to animals.

Another characteristic feature of mythological narratives is an attempt to comprehend nature by means of personifications. Samozvancev states that "the reconstruction of solar myths from different stages of the personification of the sun reveals its development from the dryad form-the sun tree, to the zoomorphic 
form-the three-legged crow, semi-zoomorphic-half bird, half woman, and entirely anthropomorphic deity-Xihe, the mother of ten suns (Samozvancev 2000 , p. 253). He indicates that the Chinese represented a rainbow as a curved dragon with heads at its ends, differentiating between hong rainbow-male dragon in prevailing light colours, and $n i$ rainbow-female dragon in dark colours. The wind was also personified in different images of the wind spirit Feng Bo- as a dog with a human face, a bird, a comet, or associated with another mythological creature Fei Lian that looked like a deer with the head of a bird, a tail of a snake and leopard spots. The world hostile to humans was represented as a huge boar, an awful maneating boa, a fierce bird raising "great wind," etc. (Ibid, p.p 266-268).

The fauna of the mythological narrative is constructed in a similar way as the world of human-like characters. It is inhabited by fictitious animals, hybrids, and real animals.

The four sacred mythological animals are the Dragon, the Phoenix, the Qilin, and the Turtle.

The Dragon is a male creature, the personification of strength, happiness, and well-being, a protector of people and the symbol of the Chinese nation as a whole. This is a hybrid snake-like creature with the horns of a deer, the head of a camel, the eyes of a rabbit, the ears of a bull, the neck of a snake, the scales of a carp, the claws of an eagle, and the paws of a tiger.

The Fenghuang, or Phoenix, is a female bird, up to three meters tall; from the front it looks like a swan, and from the back-like a qilin; it has the face of a swallow, the beak of a cock, the neck of a snake, the body of a turtle, and the tail of a fish.

The Qilin is a wonder creature with one or two horns, a body covered with blue or green scales, with horse or deer hooves, the head of a dragon and the tail of a bear. Qilin symbolizes peace and prosperity, but appears to people very seldom, usually to annunciate the birth of a sage, and is therefore usually depicted with a male baby on the back.

The Turtle is often shown intertwined with a snake and is a symbol of longevity and endurance.

Some other inhabitants of the fictional world include: Chang'e or Chang-ogoddess of the Moon usually represented as a three-legged toad pestling the powder of immortality; black bees and moths the size of an elephant; a four-winged bird with a dog's tail; a winged tiger with spines like those of a hedgehog; a bull with a white head, one eye, and a snake's tail; a bird that looks like a snake, with four wings, six eyes and three legs; jian jian-a pair of inseparable birds, a symbol of conjugal life featured as two wild ducks (a green and a red one), each with one wing and one eye, capable of flying only together.

Real animals highly respected in myths are a tiger, a cat, a cock, a lion, a monkey, a snake, and a fox (Ezhov 2004, p. 78-80). A number of animals, birds and insects represented in Chinese fictional narratives are not typical of the Western mythological or fairy-tale tradition: a gorilla, an oriole, a flounder, a shrimp, a flying fish, a flea, a louse, etc.

Some characters are neither humans nor animals, like Hundun mentioned above- the personification of chaos, represented in pictures as an egg-like creature 
without a head, with six animal paws and four wings; or monster Shirou- "the sighted flesh" looking like a bull's liver with a pair of small eyes-an inexhaustible source of food, the favourite ailment of wise men.

On the bases of the analysis it is possible to conclude that Chinese mythological characters are numerous, diversified and represented by real people; human-like creatures; semi people, semi-animals; real animals; and creatures that are neither humans nor animals.

\section{Communicative behaviour of mythological characters}

In general, the logic of the characters' behaviour in Chinese mythological narratives is clear to the Western readers: they are sometimes happy or sad, they fall in love, get married, protect their children, work, fight for the spheres of influence, do good and bad deeds, etc. However, quite often their actions are unusual, especially from the Western point of view. E.g. Nuwa mends part of the sky that has fallen through; cuts the legs of a huge turtle and uses them to hold up the sky; collects reed ashes and with their help blocks a flood; a dragon lays out rain clouds on a stand; a fierce man-eating bull makes sounds similar to a baby wailing; a cicada turns into a shoe. Mythological characters eat stones, sand, metal, as well as jade paste and crushed mica; they swim on an iron staff and a fan. A brave girl puts rice pancakes with honey sauce near the entrance to a cave to lure out a monster and then kills it with a sword; a local rich man impressed by her feat marries her. The inhabitants of one of the foreign lands walk on their toes without touching the ground with their heels and turning their feet so that, when they walk to the south, their footsteps point to the north. Some people's tongues grow in the direction of their throat, so when they talk they do not understand each other. God Bazha calls locusts to court and chains them.

Fictional characters are born in an unusual way; from a glance or from swimming in a Yellow Pond; from a diamond, put into a woman's womb; out of a man's armpit; they grow on trees or are hatched from eggs. A woman who has difficulty giving birth makes an incision in her armpit and delivers three babies. The communicative behaviour of Chinese mythological characters contributes to the fictional nature of narratives creating their own logic and system of meanings.

\section{Conceptualization and categorization of reality}

In Chinese history there existed different models that were used to explain the construction of the world.

1. The two-part model is based on the division of yin and yang. Yin became a symbol of femininity, north, darkness, death, earth, moon, even numbers, etc. Yang is associated with masculinity, south, light, life, sky, sun, and odd numbers (Samozvancev 2000; Ezhov 2004).

2. The tree-part model that was used in Ancient China juxtaposes sky-earthhuman being; sky-mountains-waters; wood-fire-water, etc. 
3. The five-part model corresponds to the division of space into the four sides of the world plus the middle, or the centre.

The latter classification deserves special attention. According to it, each of the mythological rulers of a particular side of the world corresponded to a particular prime element, season, animal and body part, which testifies to the emergence of a complex hierarchical system of constantly interacting components, as well as the possibility of expressing the same ideas with the help of different codes: space, time, animal, colour, anatomical parts, etc.: (Samozvancev 2000, p. 273).

The Taoist five-part model of the world represents the so called "circle of creation," according to which all the prime elements are connected with each other-they produce and destroy each other: Wood (Tree) was produced by Water and destroys the Earth by drawing all juices out of it; Fire is produced by burning Wood and destroys (melts) Metal; the Earth is produced by Fire (or rather the ashes from the fire) and destroys Water by polluting it; Metal in the form of oar is produced by the Earth and destroys Wood (cuts it); Water is produced by melting Metal and is destroyed by Fire which swallows it (McLeish 1996, p. 196).

The symphony of inner feelings in Chinese music is based on five notes. Number five is the basis of the following lines from "Dao De Jing", the main source of Taoism: "Five colours blind the human eye. Five notes deafen human ears. Five tastes torture the palate..." (qtd. from: Plotnikova and Jujshina 2008, p. 147).

The five-part model clearly demonstrates the difference between the Chinese and the Western categorization of the world. Let us take a look at some parameters of the Chinese categorization (Ibid, p. 147):

colors: green/blue (non-differentiated), red, yellow, white, black/dark-blue (nondifferentiated);

seasons: spring, summer, intermediate season, autumn, winter;

time of day/night: morning, noon, evening, sunset, midnight;

sounds: sigh, laughter, song, weeping, groan;

poisons: snake, scorpion, centipede, toad, spider;

smells: musty, burnt, fragrant, fishy, rotten;

fruits: plum, apricot, jujube, peach, chestnut; etc.

The models described above reflect the structure, interrelation of elements, complex correlation of factors representing the essence of life in a way in which it was perceived at the time of the emergence of those classifications. These models play an important role in Chinese mythology, providing a system of interrelated notions, harmonizing the fictional worlds and bringing them into motion.

\section{Cultural symbols}

In Chinese mythological narratives are also very specific, which is proved by means of semiotic and stylistic analyses. We have already mentioned the systematization of the world through the use of different symbols (colours, time, space, etc.). The symbolic function is also performed by miraculous plants, the most significant of 
which is a peach - a symbol of immortality, beautiful woman and bride. God Shouxing was featured as an old man carrying a peach of longevity. The fruits of immortality grow on a magic peach tree. The peach is one of the fruits named in the five-part model of the world. Pine and pomegranate also belong to the highly valued plants.

Beauty and wealth are symbolized by precious stones. The palaces of mythological rulers are often decorated with jade, jasper, and pearl trees. Jade plays a special role as a Chinese cultural symbol and is used more frequently than others: Yu Di, the ruler of the world in Taoist mythology, is referred to as Jade Emperor; in the estates of divine characters, next to their celestial temples, there are jade terraces and ponds, as well as rich buildings made of jade and gold; the tender skin of people of heavenly beauty is compared to jade; the voice of a female spirit is melodic as the ring of jade pendants; the water flowing out of a jade rock on the island Yingzhou tastes like wine and gives people longevity; jade juice is added to the elixir of immortality; a goblet made of white jade shines at night and by sunrise is filled with sweet dew which prolongs the life of those who drink it.

Jasper is used as a similar symbol: Jade Emperor is sometimes called Jasper ruler; myths speak about jasper tower, jasper pond, etc.

Symbolism of numbers. Some of the symbolic meanings of numbers connected with Chinese mythology include:

1-Dao (man's way); Progenitor, supreme god Shangdi;

2-Yin and Yang;

4-sacred animals: Dragon, Phoenix, Qilin, Turtle;

7-Seven Taoist skies;

10 - the earth and three islands of the immortal in the Eastern sea: Fangzhang, Yíngzhou and Penglai.

12-twelve cyclic signs: Rat, Ox, Tiger, Rabbit, Dragon, Snake, Horse, Sheep/ Goat, Monkey, Rooster, Dog, Pig;

The tendency towards accuracy in the use of numbers, as well as indication of concrete time and place, agrees with the opinion of scholars who believe that Chinese people tend to think in concrete and symbolic terms, unlike Europeans whose thinking is notional and abstract (Devjatov and Martirosjan 2002. Qtd. from: Plotnikova and Jujshina 2008, p. 63).

Chinese symbols are numerous, their interpretation requires a high level of cultural and linguistic competence, and their indepth meaning is often lost on modern readers, especially from foreign cultures.

\section{Logic of meaning}

Another interesting parameter of understanding Chinese mythological narratives is the logic of thinking of their authors, which A. V. Smirnov calls the logic of meaning. He believes that, in addition to the mere sum of cultural facts, it is important to take into account the "procedure of meaning construction," "the configuration of senses," an addition of sorts to the meaning of the constituents, 
which transforms the meaning of the whole (Smirnov 2001, pp. 138-139), producing a new quality. Scholars indicate that there is a special logic in Chinese mythological discourse, which reflects a vision of reality and system of logic different from European and cannot be judged or understood with the use of the habitual Western criteria. This includes the explanation of mysteries of nature, motives and logic of characters' actions, values and beliefs as the roots of their communicative behaviour, associations behind imagery and fictional objects, etc.

\section{Conclusion}

The paper shows that Chinese mythological narratives construct a unique fictional world reflecting the peculiarities of Chinese mentality, based on a culturally specific worldview and logic. While trying to interpret Chinese fictional discourse, it does not make sense to proceed from the worldview and logic generally accepted in the West because it is based on a different system of values, beliefs and convictions.

Though the analysed narratives display certain similarities with the mythological systems of other origins, e.g., Greek and Roman, (like the existence of a pantheon of gods, heroes, hybrid creatures, the realm of the dead, wondrous transformations and conceptions; characters as the personification of good and evil, etc.), it is important to note a greater variety of forms and unexpected turns of fantasy, which seem amazing from the perspective of European logic.

Summing up the analysis, it is possible to conclude that the Chinese fictional world is (1) ethnocentric; (2) densely populated; (3) highly variable; (4) possesses a hierarchical structure; (5) is characterized by a complex system of social connections (based on kinship, age, gender, material possessions, geographical location, etc.); (6) has distinct cultural specifics; (7) is characterized by a high degree of precision and accuracy of perception; (8) reflects a peculiar system of categorization and conceptualization of reality; (9) uses multiple symbolic coding forms (systems) (10) follows a logic of meaning, which is sometimes different from the one accepted in the West.

It would be incorrect to assert that people in modern China use the old mythological concepts and notions in their interpretation of the world; however, like in other nations, the magic images of fictional worlds are preserved as a cultural background, on the level of the 'collective unconscious,' which is reflected in the 'extension' of the mind, fantasy, and metaphoric vision. The effect of mythological thinking on the Chinese population is respect for the past, worship of ancestors, attention to detail, high creativity, scientific potential, and the ability to model possible worlds. All these characteristics can be extrapolated to the social practices in modern China.

The findings indicate that the results of the research can be further extended to other types of Chinese narratives and can lead to their practical application in text interpretation, education, literature studies, and intercultural communication contexts. Detailed interpretation of complex meanings expressed in narratives of different kinds can lead to a deeper understanding and harmony between China and the outside multicultural world. 
Acknowledgments The research is supported by Grant No 15-04-00500 of the Russian Foundation for Humanities.

\section{References}

Bally, C. (1932). Linguistique générale et linguistique française. Paris: E. Leroux.

Barthes, R. (1957). Le mythe aujourd'hui. In Mythologies (pp. 181-233). Paris: Éditions du Seuil.

Burr, V. (1995). Introduction to social constructionism. London, New York: Aldine De Gruyter.

Carbaugh, D. (1996). Situating selves: The communication of social identities in American Scenes. Albany, NY: State University of New York Press.

Chinese Tales. http://oaks.nvg.org/chinese1-3.html. Accessed 6 June, 2015.

Cronen, V. E. (1996). The consequentiality of communication and the recapturing of experience. In: The consequentiality of communication. Hillsdale: Lawrence Erlbaum.

Devjatov, A., \& Martirosjan, M. (2002). Kitajskij proryv i uroki dlja Rossii [Chinese breakthrough and lessons for Russia]. Moscow: Veche.

Encyclopedia of Mythological World. (1999). A. Cotterell (Ed.). Bath: Barnes \& Noble Books.

Ezhov, V. V. (2004). Mify Drevnego Kitaja [Myths of Ancient China]. Moscow: OOO Izdatel'stvo AST.

Genette, G. ([1972] 1980). Narrative discourse: An essay in method. Ithaca: Cornell.

Genette, G. ([1983] 1988). Narrative Discourse Revisited. Ithaca: Cornell UP.

Gergen, K. J. (1991). The saturated self: Dilemmas of identity in contemporary life. New York: Basic Books.

Jahn, M. (1999). Speak, friend, and enter: garden paths, artificial intelligence, and cognitive narratology. In D. Herman (Ed.), Narratologies new perspectives on narrative analysis (pp. 167-194). Columbus: Ohio State UP.

Ke, Y. (1965). Mify Drevnego Kitaja [Myths of Ancient China]. Moscow: Nauka.

Kitajskaja mifologija [Chinese mythology]. http://godsbay.ru/orient/china.html. Accessed 20 June, 2015.

Kuyarova, P. I. (2007). Interpretacija ponjatija "social'nyj konstrukcionizm” v sociologii [Interpretation of the concept "social constructionism" in sociology]. Vestnik Samarskogo gosudarstvennogo universiteta [Journal of Samara state university]. No 1 (51) (pp. 64-70).

Lévi-Strauss, C. (1955). The structural study of myth. Journal of American Folklore, 68, 428-444.

Lévi-Strauss, C. ([1958] 1963). Structural Anthropology. New York: Basic Books.

Lyotard, J. F. (1998). Sostojanie postmoderna [The Condition of Postmodernity]. St. PetersburgMoscow: ALETEJJA.

Makarov, M. L. (2003). Osnovy teorii diskursa [Foundations of discourse theory]. Moscow: Gnozis.

McLeish, K. (1996). Myth. Myths and legends of the world explored. London: Bloomsbury.

Mifologicheskij slovar' [Mythological Dictionary]. (1990). E. M. Meletinsky (Ed.). Moscow: Soviet Encyclopedia.

Pearce, W. B. (1994). Interpersonal communication: Creating social worlds. New York: Southern Illinois University Press.

Plotnikova, L. I., \& Jujshina, E. A. (2008). Kitajskaja mental'nost'v legendah i skazkah: jetnopsiholingvisticheskij aspect [Chinese mentality in legends and fairy-tales]. Chita: Izd-vo ZabGGPU.

Powers, J. H. (1994). Public speaking: The lively art. New York: HarperCollins.

Propp, V. (1928). Morfologija skazki [Morphology of the Folktale]. Leningrad.

Rodin, I. O. (2004). Introduction. Ezhov, V. V. (2004). Mify Drevnego Kitaja [Myths of Ancient China]. Moscow: OOO Izdatel'stvo AST. (pp. 5-38).

Samozvancev, A. M. (2000). Mifologija Vostoka [Mythology of the East]. Moscow: ALETEJJA.

Saussure, F. De (1916) Cours de linguistique générale, ed. C. Bally and A. Sechehaye, with the collaboration of A. Riedlinger, Lausanne and Paris: Payo.

Stoljarova, O. E. (2003). Social'nyj konstruktivizm: ontologicheskij povorot [Social constructionism: ontological turn]. Vestnik Moskovskogo universiteta [Journal of Moscow University]. Serties 7. Philosophy. No 3. (pp. 39-51).

Shilkov. Y. M. (2002). Ja (A.Slinin) i MY [Me (A. Slinin) and Us]. St. Petersburg: Sankt-Peterburgskoe filosofskoe obshhestvo [St. Petersburg Philosophical Society]. Series X. http://anthropology.ru/ru/ texts/shilkov/slinin.html. Accessed 3 Nov, 2014. 
Smirnov, A. V. (2001). Logika smysla: teorija i ee prilozhenie $k$ analizu klassicheskoj arabskoj filosofii $i$ kul'tury [Logic of meaning: theory and its application to the analysis of classical Arabic philosophy and culture]. Moscow: Jazyki slavjanskoj kul'tury.

Smith, N. (2003). Sovremennye sistemy psihologii [Modern systems of psychology]. Saint-Petersburg: Prajm-Evroznak.

Spector, M., \& Kitsuse, J. (1977). Constructing social problems. CA, Cummings: Menlo Park.

Stoljarova, O. E. (2003). Social'nyj konstruktivizm: ontologicheskij povorot [Social constructionism: ontological turn] (afterword to Latour's paper). Vestnik of Moscow State University., 7(3), 39-51.

Van Dijk, T. A. (1981). Discourse Studies and Education. Applied Linguistics, 2, 1-26.

Walsh, R. (2007). The rhetoric of fictionality: narrative theory and the idea of fiction. In Theory and interpretation of narrative. Columbus: The Ohio State University Press.

Werner, E. T. C. (2005). Myths and Legends of China. http://www.gutenberg.org/files/15250/15250-h/ 15250-h.htm\#d0e1278. Accessed 10 June, 2015. 